\title{
Altered organic matter dynamics in rivers and streams: ecological consequences and management implications
}

\author{
Arturo Elosegi and Jesús Pozo
}

Faculty of Science and Technology, the University of the Basque Country UPV/EHU, PoBox 644, 48080 Bilbao, Spain.

*Corresponding author: arturo.elosegi@ehu.eus

Received: $15 / 02 / 2016$

Accepted: 05/05/2016

\begin{abstract}
Altered organic matter dynamics in rivers and streams: ecological consequences and management implications

Scientists have spent decades measuring inputs, storage and breakdown of organic matter in freshwaters and have documented the effects of soil uses, pollution, climate warming or flow regulation on these pivotal ecosystem functions. Large-scale collaborative experiments and meta-analyses have revealed some clear patterns as well as substantial variability in detritus dynamics, and a number of standardized methods have been designed for routine monitoring of organic matter inputs, retention and breakdown in different conditions. Despite the knowledge gathered, scientists have been relatively ineffective at convincing managers of the importance of organic matter dynamics in freshwaters. Here we review the existing information of the role of organic matter as a) an element structuring freshwater habitats, b) a source or sink of nutrients, c) a food resource for heterotrophs, d) a source of pollution, e) a modulator of the fate of pollutants, f) a source of greenhouse gases, g) a potential source of environmental problems, and h) a diagnostic tool for ecosystem functioning. Current knowledge in some of these points is enough to be transferred to management actions, although has seldom been so. Some other points, such as the interactions between organic matter and emerging pollutants, offer interesting research questions.
\end{abstract}

Key words: Detritus, large wood, litter, freshwaters, management.

\section{RESUMEN}

Alteraciones en la dinámica de la materia orgánica en ríos y arroyos: consecuencias ecológicas e implicaciones para la gestión

Los científicos han pasado décadas midiendo las entradas, la acumulación y la descomposición de materia orgánica en aguas continentales y han documentado los efectos de usos del suelo, de la contaminación, del calentamiento climático o de la regulación de caudales en estas funciones ecosistémicas fundamentales. Experimentos de colaboración a gran escala y meta-análisis han revelado algunos patrones claros, así como gran variabilidad en las dinámicas detríticas; también se han diseñado un buen número de métodos estandarizados para la determinación rutinaria de las entradas, retención y descomposición de materia orgánica en distintas condiciones. A pesar de dichos esfuerzos, los científicos hemos sido relativamente ineficaces a la hora de convencer a los gestores de la importancia de las alteraciones en la dinámica de la materia orgánica en aguas continentales. Aquí revisamos la información existente sobre el papel de la materia orgánica como a) un elemento estructurador de los hábitats acuáticos, b) una fuente o sumidero de nutrientes, c) un recurso alimenticio para los heterótrofos, d) una fuente de contaminación, e) un modulador del destino de otros contaminantes, f) una fuente de gases de efecto invernadero, $g$ ) una fuente potencial de problemas ambientales y h) una herramienta para diagnosticar el funcionamiento de los ecosistemas. El conocimiento existente en alguno de dichos campos es suficiente para ser transferido a acciones de gestión, aunque raramente lo ha sido. Otros puntos, como las interacciones entre materia orgánica y contaminantes emergentes, ofrecen preguntas de investigación interesantes.

Palabras clave: Detritus, madera, hojarasca, aguas continentales, gestión. 


\section{ORGANIC MATTER IN FRESHWATERS, A GROWING RESEARCH FIELD}

Detritus, or dead organic matter (hereafter OM), is a very abundant but generally poor-quality food resource in most ecosystems (Moore et al., 2004). Freshwater scientists have since long acknowledged the pivotal role of OM in stream and river ecosystems, and the importance of organic inputs of terrestrial origin, especially in forested streams where shading by the riparian vegetation limits primary production (Kaushik \& Hynes, 1971; Vannote et al., 1980), but also in other lotic systems (Hill \& Webster, 1983).

Riverine detritus is diverse in nature, and it is commonly categorized by its size (Fig. 1). Dissolved organic matter (DOM), defined usually as the fraction not retained by filters of $0.2-0.45 \mu \mathrm{m}$ pore size, can be derived either from the basin, especially soil leachates (Fiebig, 1992), or from autochthonous producers (Kaplan \& Bott, 1989), and is often the largest pool of OM in running waters (Karlsson et al., 2005). Although DOM tends to be dominated by recalcitrant forms such as hu- mic substances (Battin et al., 2003), it can be an important energetic resource for heterotrophic microbes (Bano et al., 1997). Fine particulate organic matter (FPOM), constituted by particles in the range of $0.45 \mu \mathrm{m}$ to $1 \mathrm{~mm}$, is a poorly known fraction of $\mathrm{OM}$, despite its importance as a food source for stream collectors (Bundschuh $\&$ McKie, 2015). It includes fragments of leaves and other materials, pollen, algal cells, and faeces of invertebrate consumers (Bonin et al., 2000; Kendall et al., 2001; Joyce \& Wotton, 2008). Coarse particulate organic matter (CPOM) is the fraction larger than $1 \mathrm{~mm}$, usually dominated by leaves, but which also includes other plant material such as bark, twigs, fruits and flowers (Pozo et al., 1997), plus coarse particles of animal origin, which, although less abundant, can be extremely important for riverine consumers such as trout (Baxter et al., 2004). Finally, large wood (LW) is the fraction of detritus made up by large branches, logs and trees (thicker than $10 \mathrm{~cm}$ and longer than $1 \mathrm{~m}$ ), that can be extremely abundant in some streams and rivers, playing a major geomorphic role (Nakamura \& Swanson 1993), in

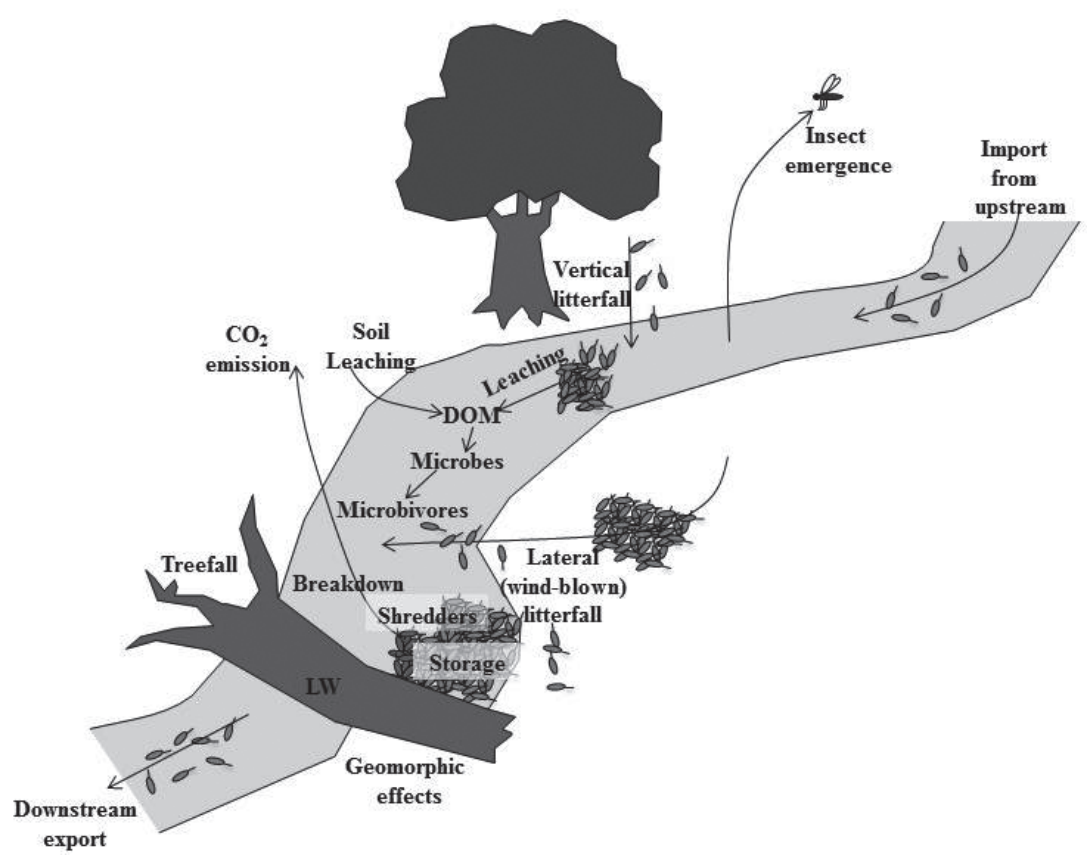

Figure 1. Main components and pathways of OM in stream ecosystems. Principales componentes y vías de transformación de la materia orgánica en ecosistemas fluviales. 
addition to being an important trophic resource (Collier \& Halliday, 2000; Elosegi et al., 2007).

A large number of now classic papers studied the inputs (Fisher \& Likens, 1972), characteristics (Webster et al., 1990), retention (Ehrman \& Lamberti, 1992), storage (Smock, 1990), transformations and breakdown (Petersen \& Cummins, 1974) of OM, its relevance for channel form and dynamism (Gurnell et al., 2000), for river ecosystem functioning (Lepori et al., 2005), as well as the potential use of breakdown as an indicator of functional integrity of streams (Gessner \& Chauvet, 2002; Young et al., 2008). The scientific literature dealing with $\mathrm{OM}$ has risen in the last decades (Fig. 2), including a number of review papers (e.g., Tank et al., 2010), as well as some books (Gregory et al., 2003). In these, researchers have documented how riverine $\mathrm{OM}$ and its breakdown are affected by land uses (Ferreira et al., 2015; 2016), pollution (Niyogi et al., 2001), climate warming (Ferreira \& Canhoto, 2014) or flow regulation (Ponsatí et al., 2014), among other human impacts, and their dynamics show a great variability (Pozo, 2005). Large-scale collaborative experiments



Figure 2. Number of papers published on OM breakdown in streams according to the ISI Web of Science in June 2014, with the following search criteria: Topic: ((stream or river) AND ("organic matter" or litter) AND (decomposition or breakdown)); Field: Environmental Sciences and Ecology; Document type: Article. The total output was 2095 papers. Número de artículos publicados sobre la descomposición de materia orgánica en ríos según el ISI Web of Science en junio de 2014, según los siguientes criterios de búsqueda: Tópico: ((río o arroyo) Y ("materia orgánica" o hojarasca) Y descomposición)); Campo: Environmental Sciences and Ecology; Tipo de documento: Artículo. El número total de artículos fue de 2095.
(Woodward et al., 2012) and meta-analyses (Ferreira et al., 2016) have revealed some clear patterns, and a number of standardized methods have been designed for routine monitoring of $\mathrm{OM}$ inputs, retention and breakdown in different conditions (Graça et al., 2005; Arroita et al., 2012; Tiegs et al., 2013).

Nowadays there is consensus among scientists on the importance of OM dynamics for the ecological integrity of river ecosystems. Nevertheless, scientists seem to have been ineffective at convincing managers of the consequences of altered OM dynamics in freshwaters, and few management actions focus directly OM. Here we review the existing information of the role of $\mathrm{OM}$ as a) an element structuring freshwater habitats, b) a source or sink of nutrients, c) a food resource for heterotrophs, d) a source of pollution, e) a modulator of the fate of pollutants, $f$ ) a source of greenhouse gases, g) a potential source of environmental problems, and h) a diagnostic tool for ecosystem functioning. Our objective is to analyse the gap between scientists and managers regarding OM in streams and rivers, and to detect fields in which scientific information could be transferred into management actions, as well as fields in which more knowledge is necessary before trying such a transfer. We do not intend the review to be exhaustive, as there is a vast amount of information on OM in streams and rivers. We rather provide specific examples of the type of research performed and of their possible management implications.

\section{OM AS AN ELEMENT STRUCTURING FRESHWATER HABITATS}

One of the fields related to OM in streams and rivers in which there has been more active exchange of ideas between scientists and managers is the role of LW as a key factor structuring river habitats (Gregory et al., 2003). LW can at times accumulate in rivers in huge jams (Fig. 3; Boivin et al., 2015) whose effects were mentioned in early books on geomorphology (Lobeck, 1939). Nevertheless, it was much later, with the reviews by Keller and Swanson (1979) on its geomorphic 
effects, and the more comprehensive review by Harmon et al. (1986), that river scientists began considering LW as a key component of unimpaired river ecosystems. LW was shown to shape channel form and control river dynamism (Piégay \& Gurnell, 1997), to slow down flow and retain sediments and OM (Roberts et al., 2007), to increase the number and depth of pools (Abbe \& Montgomery, 1996), to provide refuge for salmonids and other organisms (Scealy et al., 2007) and to control island formation in large rivers (Gurnell et al., 2001). More recently, it has been shown that LW can also be a key habitat for microscopic organisms of the biofilm, to the point that the amount of LW promotes biofilm abundance and consequently enhances ecosystem functioning (Baldwin et al., 2014). All these functions can be compromised by changes in riparian vegetation, which affect the phenology and amount of LW inputs to streams (Díez et al., 2001). Therefore, the reciprocal interactions between channel form and dynamics of riparian vegetation strongly affect river geomorphic processes (Corenblit et al., 2007).

The important geomorphic and ecologic roles of LW, together with the evidence that human actions had strongly reduced its abundance in many streams and rivers (Elosegi \& Johnson, 2003; Wohl, 2014), led to many restoration projects in which logs were added into the channels, initially to improve fish habitat (Hunt, 1993), but later on with more objectives in mind, from general improvement of river geomorphology (Kail et al., 2007) to promoting retention of OM and sediments (Flores et al., 2011; Elosegi et $a l ., 2016)$. These projects are constrained by the generally negative perception of LW in streams and rivers in most countries, were woody debris is considered to be an alien, non-aesthetic and dangerous element in river channels (Piégay et

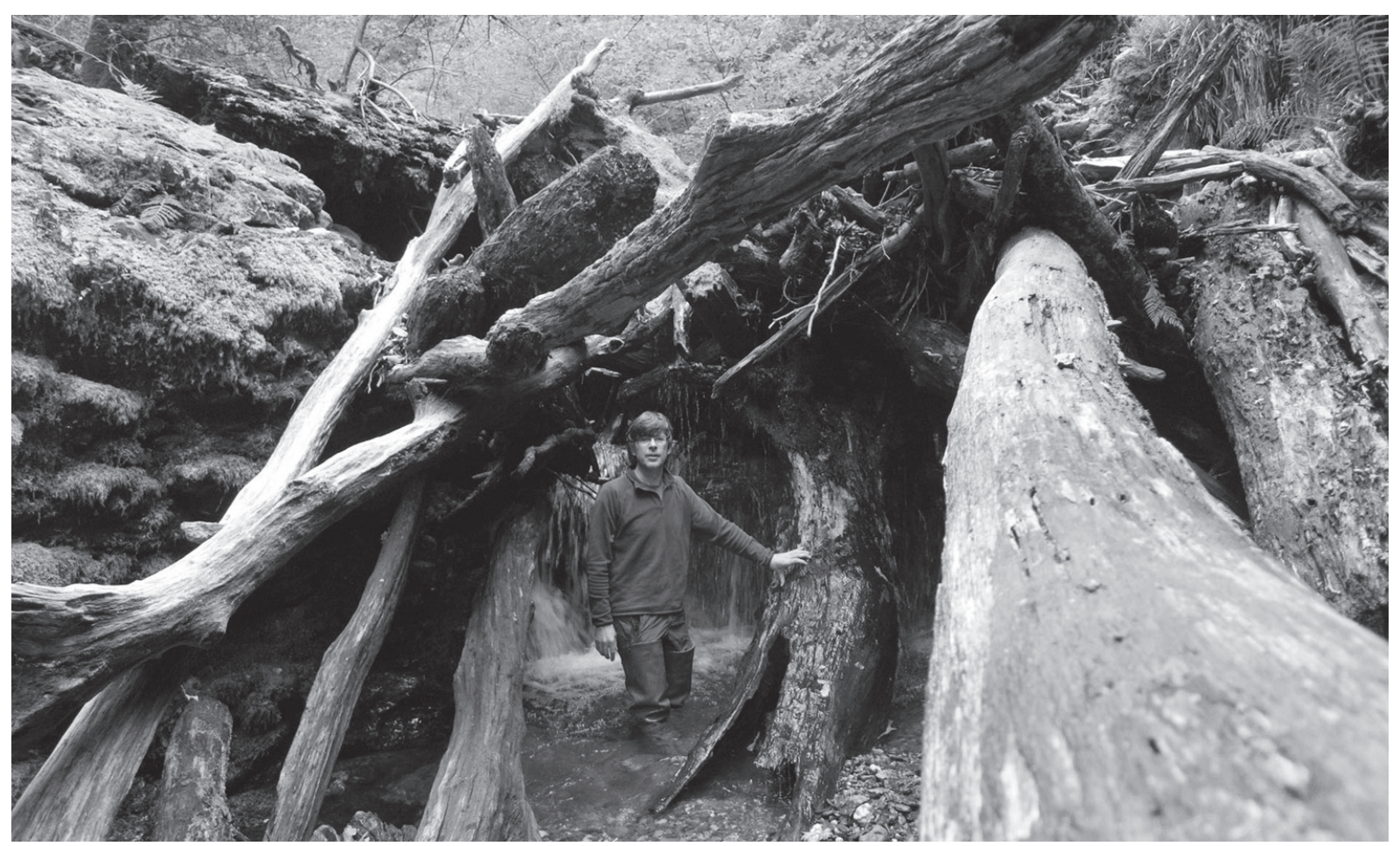

Figure 3. A large LW dam formed naturally in Urdallu Stream (Urumea River basin, Navarre). It stores a large amount of carbon and promotes the upstream retention of large volumes of sediment and leaf litter. Photo Jorge González-Esteban. Una gran presa de madera formada de manera natural en el arroyo Urdallu (cuenca del Urumea, Navarra). Almacena gran cantidad de madera y produce la retención aguas arriba de un gran volumen de sedimento y hojarasca. Foto Jorge González-Esteban. 
$a l .$, 2005). Despite these societal constrains, LW is being increasingly used in river restoration projects (Bernhardt et al., 2005a; Roni et al., 2015), which although often based on wrong scientific ideas and poorly monitored (Palmer et $a l ., 2010)$, show in general a strong interaction between managers and scientists, as exemplified in the many practical guides available for LW reintroduction (e.g., Brooks, 2006; Opperman et al., 2006).

In addition to LW, other components of detritus such as leaf litter and fine organic sediments can be important habitats for river organisms, at least for some invertebrates (Holomuzki \& Hoyle, 1990; Boulton \& Foster, 1998), but so far there are few examples of management actions focusing specifically on them (Kemp et al., 2000), maybe because these components lack the stability of LW.

\section{OM AS A SOURCE/SINK OF NUTRIENTS}

A large fraction of the nutrients in many forests are stored in OM (Whittaker et al., 1979; Attiwill \& Adams, 1993), and thus, litter breakdown has long been known to represent an important source of nutrients to forested stream and river ecosystems (Gosz et al., 1973). Many papers measured the contribution of OM to stream nutrients, either by leaching (Wallace et al., 2008) or by mineralization (Johnson et al., 2013). Although some authors reported decreased con- centration of nutrients in stream water shortly after peak leaf fall (Mulholland, 1992), and other modelled the relationship between decomposition and dissolved nutrients (Lin \& Webster, 2014), the overall effect on long-term nutrient availability or export is likely minor and probably only significant in oligotrophic streams. For instance, based on results by Pozo et al. (1998) and Molinero \& Pozo (2004, 2006), dissolved nitrogen generated by leaf decomposition represents less than $1 \%$ of the dissolved nitrogen exported by streams of the Agüera basin, both under deciduous forest and eucalyptus plantations. For phosphorus, the equivalent ratio is lower than 5\%. Other types of OM can be more important sources of nutrients, as, for instance, salmon carcasses, which enrich both streams and riparian areas alike (Helfield \& Naiman, 2006). It is also likely that the massive insect emergence in some rivers produces a net transport of nutrients to nearby areas, as has been described in some midge lakes (Gratton et al., 2008).

In addition to being a source of nutrients, OM also plays a role on the uptake and immobilization of dissolved nutrients by microbial decomposers (Mulholland et al., 1985; Molinero et al., 1996; Webster et al., 2003), on their long-term storage in LW and other refractory organic materials (Hyatt \& Naiman, 2001), and on key processes such as denitrification, which occurs in the interphase between oxidized and reduced sediments, and thus, is often spatially linked to de-

Table 1. Main findings on the storage, breakdown rate and $\mathrm{CO}_{2}$ production associated to leaf litter in north Iberian streams depending on nutrient status. Principales hallazgos sobre la acumulación, tasa de descomposición y producción de $\mathrm{CO}_{2}$ asociados a la hojarasca en arroyos ibéricos en función de su nivel trófico.

\begin{tabular}{lccc}
\hline & Oligotrophic & Mesotrophic \\
\hline Decomposition of eucalyptus leaves & slow & similar & fast \\
Eucalyptus litter standing stock & & high & high \\
$\mathrm{CO}_{2}$ production & fast & similar & fast \\
Decomposition of alder leaves & high & high \\
Alder litter standing stock & moderate & fast \\
$\mathrm{CO}_{2}$ production & & similar \\
Decomposition of leaves of intermediate quality & moderate & fast \\
Intermediate litter standing stock & & \\
$\mathrm{CO}_{2}$ production & & \\
\hline
\end{tabular}


caying OM (Hill, 1996). As an example, the decomposition rate of nutrient-poor leaves such as those of eucalyptus is strongly dependent on dissolved nutrients, being low in nutrient-poor waters and fast, close to that of alder leaves, in nutrient-rich waters (Pozo et al., 1998) (Table 1). Furthermore, the replacement of native riparian vegetation by eucalyptus plantations reduces the inputs of organic $\mathrm{N}$ and $\mathrm{P}$ to streams, but higher leaf retention at eucalyptus sites, related to phenology of inputs and hydrology, results in a benthic storage of $\mathrm{N}$ and $\mathrm{P}$ similar to that at deciduous sites (Molinero \& Pozo, 2004). Therefore, managing OM could potentially have important consequences for the flux of nutrients in streams and rivers. Other example was shown by Bernhardt et al. (2005b), who suggested that as the riparian forests mature instream nitrogen processing is enhanced as a consequence of greater abundance of LW and other OM, which enhances nutrient retention and creates patches of active denitrification. Therefore, by promoting the maturity of riparian forests and the abundance of instream LW, managers might reduce the downstream flux of nutrients. Acuña et al. (2014) showed that restoring instream $\mathrm{LW}$ in a basing draining to a drinking-water reservoir could be economically profitable in terms of enhanced ecosystem services, including nutrient retention. Ultimately, instream processes can dampen the effects of upland disturbances on nutrient export (Bernhardt et al., 2003).

Despite the above information, to our knowledge managers rarely use OM as a way to control nutrients in stream and river ecosystems. A notable exception is the experimental addition of fish carcases to recover natural nutrient regimes in rivers subject to strong declines in salmon runs, which proved to be more effective than adding nutrient pellets (Wipfli et al., 2010).

\section{OM AS A FOOD RESOURCE FOR HETEROTROPHS}

$\mathrm{OM}$ is a key food resource for riverine heterotrophs, both consumers and decomposers (Marcarelli et al., 2011). These organisms use organic matter as an energetic resource depending on its texture and chemical composition, including nutrient content and the amount of refractory and toxic substances (Casas et al., 2013; Canhoto \& Graça, 1995). The degradation of refractory compounds such as cellulose and lignin requires the action of specific enzymes that are lacking in many consumers. Therefore, detritus rich in these compounds is of low nutritional value and slow decomposition (Melillo et $a l .$, 1984). Some DOM fractions are readily used by bacteria (Hall \& Meyer, 1998), resulting in a "microbial loop" similar to that described in lentic ecosystems (Legendre \& Rassoulzadegan, 1995). On the other hand, particulate OM is colonized by microbes, especially bacteria and fungi, but also Archaea (Manerkar et al., 2008), to the point of controlling their biomass and activity (Artigas et al., 2008). These microbes, in turn, are consumed by micro- and meiofauna (Gaudes et al., 2009), and promote consumption by macroinvertebrates (mainly shredders but also collectors) through enhanced palatability (Hieber \& Gessner, 2002). Therefore, the energy contained in OM spreads bottom up to the entire aquatic food web (Wallace et al., 1997) and even to the surrounding terrestrial environment through aquatic-terrestrial trophic linkages such as spiders, bats and birds feeding on emerging insects (Baxter et al., 2004; Kautza \& Sullivan, 2015). Interestingly, in addition to the transfer of energy, these "reciprocal subsidies" (Nakano \& Muramaki, 2001) also account for the transfer of contaminants from the aquatic to the terrestrial realms (Runck, 2007; Alberts et al., 2013).

Many factors affect the importance of $\mathrm{OM}$ as a food resource. OM availability depends on the amount of inputs, which are a function of the type and maturity of riparian vegetation (Webster \& Meyer, 1997), the mobility of leaves, which depends on species (Fig. 4), and the capacity of stream channels to retain and store OM over long periods (Flores et al., 2011). The latter depends, among others, on channel complexity, and very especially on the amount of LW (Quinn et al., 2007), which is the most retentive structure, especially at high flows (Larrañaga et al., 2003). On the other hand, food quality depends mainly 
on the composition of the riparian forest, as tree species can differ greatly on the nutritional quality of their leaves (Petersen \& Cummins, 1974; Melillo et al., 1984), but also on deposition site (Flores et al., 2013), probably because it affects its stability and, thus, the capacity of microbes to colonize and condition the trapped material. Changes in riparian vegetation seem to affect decomposers less than detritivores (Ferreira et al., 2015). Other environmental factors affecting the use of OM include hydraulics (Ehrman \& Lamberti, 1992; Jones \& Smock, 1991) as well as the concentration of nutrients in water (Gulis \& Suberkropp, 2003).

The importance of $\mathrm{OM}$ as a food resource and the potential implications for ecosystem functioning of the amount and quality of OM stored in the channel have been stressed out in several research papers that directly manipulated OM inputs (Larrañaga et al., 2006; Richardson, 1991) and suggest ways to manage stream and river ecosystems to enhance basal resources and consumers. These include controlling the cover, composition and maturity of riparian forests, managing channel retention capacity, and so on. Nevertheless, we are no aware of management actions specifically focusing $\mathrm{OM}$ as food, with the exception of a few experiments introducing OM-trapping structures (Dobson et al., 1995; Tiegs et al., 2011).

\section{OM AS A SOURCE OF POLLUTION}

Excess OM inputs can have detrimental effects on freshwater ecosystems, including oxygen depletion, eutrophication, and problems associated with human health (Harper, 1992). There is an extensive body of literature dealing with the impacts, treatment and prevention of the effects of high biological oxygen demand (BOD) and chemical oxygen demand (COD, e.g., Sullivan et al., 2010), and modelling their impact on oxygen concentration (e.g., Fornasini, 1991). BOD and COD have been incorporated into the water legislation such as the EU Water Framework Directive, and their inputs are now regulated in most of the world. On the other hand, the

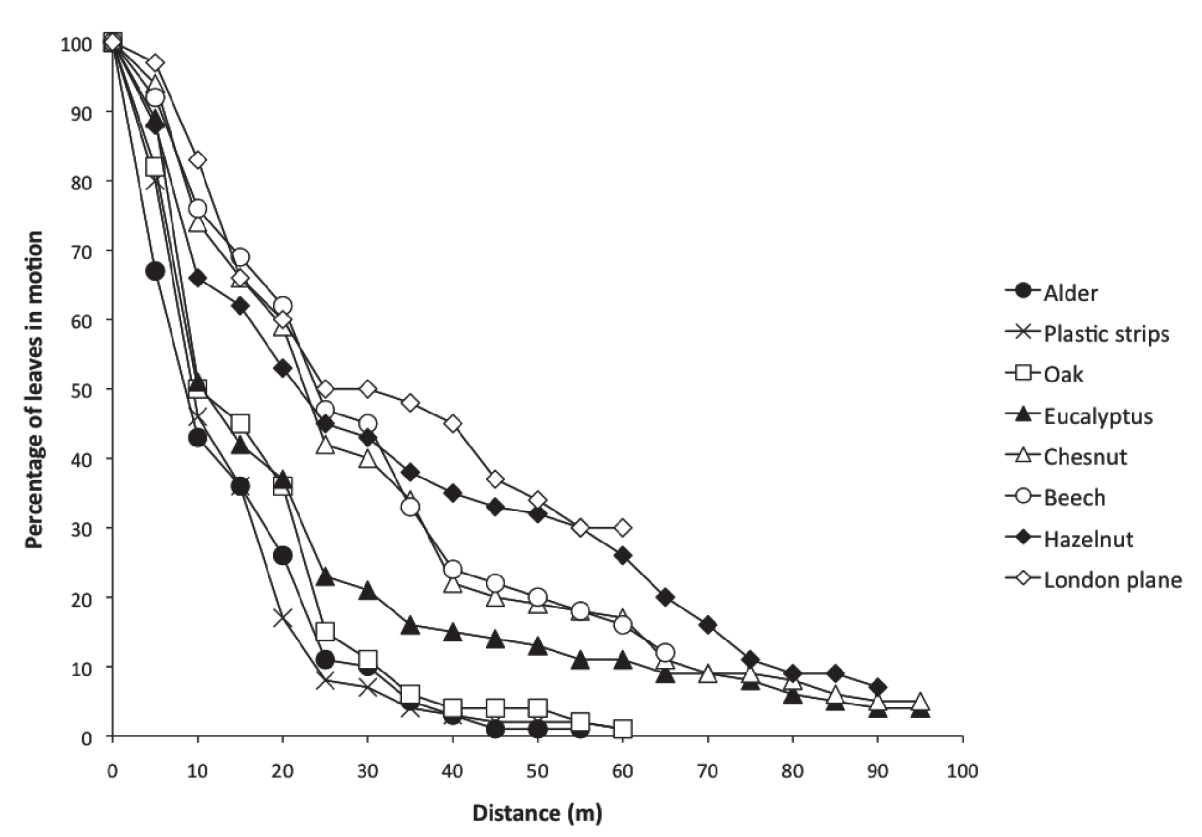

Figure 4. Distances travelled by plastic strips and different leaf species of the riparian vegetation in the Agüera Stream (northern Spain) at baseflow. Mean values are reported by Larrañaga et al. (2003). Distancias recorridas por tiras de plástico y distintas especies de hoja de la vegetación riparia en el río Agüera (norte de España) en caudales basales. Los valores medios fueron publicados por Larrañaga et al. (2003). 
detrimental effects of excess OM in freshwaters led, among others, to consider OM as a pollutant, and to develop bioindication methods such as the Saprobian method (Lange-Bertalot, 1979), or specific diatom indices (Kelly \& Whitton, 1995). Therefore, this is one aspect of OM in streams and rivers that is already well incorporated into management.

On the other hand, there is a growing concern on the environmental and health effects of a large range of organic substances, included in the so-called emerging contaminants (Loos et al., 2009; Pal et al., 2010). These include pesticides, pharmaceuticals and personal care products, natural and synthetic hormones, alkylphenols and other substances related to detergents, and perfluorinated compounds, among many others (Petrovic et al., 2013). Many of these substances have very powerful biological effects, but their effects in nature are little known, especially in the case of complex mixtures, such as wastewater treatment plant (WWTP) effluents (Gros et al., 2007). Clearly, there is a lot to learn on the fate and effects of these organic contaminants, and of their degradation products, which can in some cases be more harmful than the parent compounds (Schulze et al., 2010). Therefore, there is an increasing number of calls for incorporating at least some of these contaminants into monitoring programs, as they represent a challenge for water resource management in the near future (Geissen et al., 2015).

\section{OM AS A MODULATOR OF THE FATE OF POLLUTANTS}

OM modulates the fate of pollutants in multiple ways, including their storage, mobility, persistence, toxicity and bioaccumulation (Chapman et al., 1998; Redman et al., 2002; Eggleton \& Thomas, 2004), as well as by controlling the main biogeochemical routes through its effects on the riverine chemical environment, especially on the redox potential (Kim et al., 2008).

Dissolved, flocculated or particulate OM can adsorb multiple pollutants, as shown, for instance, by Stankus et al. (2011) for gold nanopar- ticles or by Sounthararajah et al. (2015) for heavy metals. Similarly, dissolved organic carbon (DOC) and leaf leachates are known to interact with metal mobility (Guibaud et al., 2000; Tsui et al., 2008), and the organic content of sediments tends to increase the sorption of hydrophobic pollutants (Karickhoff et al., 1979). Additionally, there are many papers showing an effect of OM on pollutant toxicity and bioaccumulation. For instance, Lambertson and Nilsson (2006) showed that OM is the main control of mercury toxicity in estuarine sediments, and Granier et al. (1999) showed that DOM modulates bioaccumulation of PCB by Daphnia.

On the other hand, OM exerts strong effects on the riverine chemical environment, which, in turn, can affect the fate of pollutants. Especially important is the redox potential, which controls, among others, the nitrification and denitrification processes (Knowles, 1982), as well as the mobilization of metals and other toxicants (Kalbitz \& Wennrich, 1998). Therefore, local OM accumulations can have important consequences for the fate of these toxic compounds. This has sometimes been transferred to management, such as in projects of riparian wetland restoration to enhance self-purification. Although the physicochemical basis of the interactions among types of pollutants and different fractions of organic matter is beyond the scope of the present review (and beyond the knowledge of the authors), there is room to improve management. For example, managers may increase or reduce the inputs or retention of $\mathrm{OM}$ in a reach to enhance or reduce retention of toxicants. Or narrow the stream channel to increase flow velocity and flush OM and toxicants downstream. We are unaware of management measures along these lines.

\section{OM AS A SOURCE OF GREENHOUSE GASES}

Streams and rivers cover only a minute part of the Earth surface, and have traditionally been considered as biologically little reactive compared to terrestrial ecosystems. This fact, along with the lack of good metabolism data 
for most rivers in the world, explains why river ecosystems are usually not incorporated into national greenhouse gas statistics. Nevertheless, it has recently been estimated that streams and rivers of the world transport, transform or store nearly $2.7 \mathrm{Pg}$ of terrestrial organic carbon per year, a quantity that almost equals the size of the terrestrial carbon sink for anthropogenic emissions (2.8 Pg/y, Battin et al., 2009). These figures would increase if we consider intermittent rivers and ephemeral streams, which are extremely abundant worldwide (Acuña et al., 2014), and which can be very active at emitting greenhouse gases (von Schiller et al., 2014). Furthermore, experimental evidence suggests that global climate change may enhance $\mathrm{CO}_{2}$ evasion by streams and rivers (Boyero et al., 2011). Especially worrying from the point of global climate change are emissions of $\mathrm{CH}_{4}$, associated to anaerobic decomposition of $\mathrm{OM}$, which are common in freshwater ecosystems such as rice fields (IPCC, 2007) and reservoirs (Bastviken et al., 2011), and which are caused in part to flooded plant and soil material (Barros et al., 2011). On the other hand, LW can be an important $\mathrm{C}$ reservoir in headwater streams (Beckman $\&$ Wohl, 2014). We are not going to develop into detail the effect of rivers on global warming, which would be beyond the scope of the present review, but we want to stress out the fact that river management can play a role in the global management of greenhouse gases, and thus, should

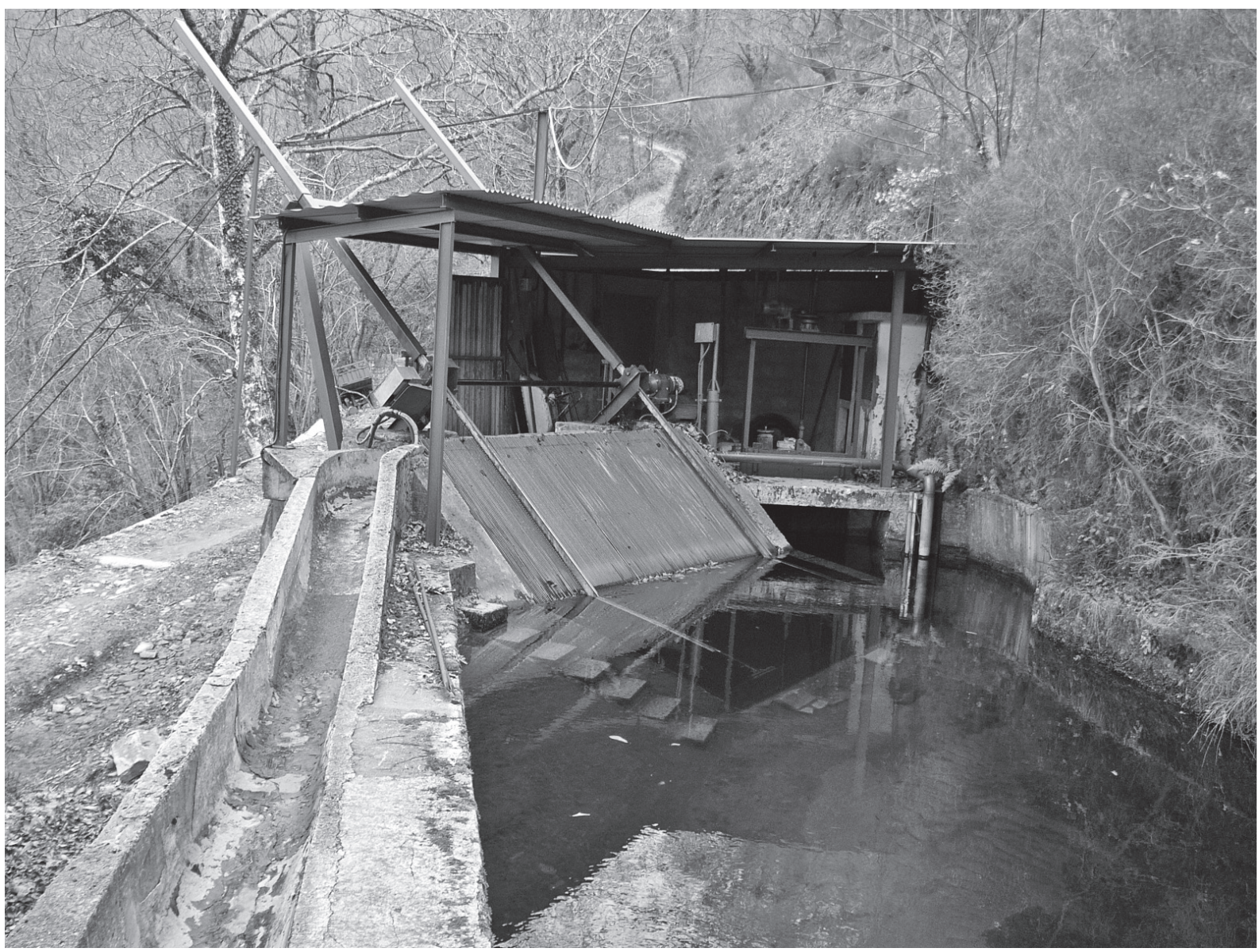

Figure 5. An automatic rake to prevent OM entering the turbines in a small hydropower plant in Añarbe Stream, the Basque Country, Spain. Una rejilla automática para evitar la entrada de materia orgánica a las turbinas de una pequeña planta hidroeléctrica en el arroyo Añarbe, País Vasco, España. 
be taken into account, from national accounting of emissions to carbon management plans.

\section{OM AS A POTENTIAL SOURCE OF ENVIRONMENTAL PROBLEMS}

OM can cause other serious environmental problems. For instance, POM can accumulate around water intakes installed in streams, lakes, and reservoirs, preventing efficient withdrawal of water for drinking, farming and power generation (Namihira et al., 2009). In fact, many withdrawal schemes such as small hydropower plants have been forced to install rakes or other expensive devices to maintain their installations free from organic matter (Fig. 5). Similarly, floating logs can produce damages, clog bridges (Wu et al., 2014; Lucía et al., 2015) and increase flood hazard during spates (Ruiz-Villanueva et al., 2014). They can also be a problem for river as well as coastal navigation (Doong et al., 2011). Drifting wood causes an increasing number of problems in many regions such as Europe, because of the intense afforestation registered after the 1950s (Liébault \& Piègay, 2002). The most common management measure is to remove logs fallen into stream and river channels and the thinning of riparian forests (Boyer et al., 2003), but these are often expensive and of small efficiency. Other mechanisms such as log traps have been implemented experimentally in some rivers. We are not giving solutions here for such a complex problem, but clearly, managers should be aware of it. Although old bridges are extremely expensive to modify, when designing and building new bridges, engineers should take in account the oncoming wood loading regime, thus making them less prone to form log jams. Ironically, whereas most flood control programs still focus mainly on hard engineering measures such as channelization, the European Union is now promoting the introduction of LW in some streams as an experimental measure to enhance natural water retention and to reduce downstream peak flooding (http://www.nwrm.eu/).

\section{OM AS A DIAGNOSTIC TOOL}

Given the pivotal role of OM inputs, retention, storage and breakdown in stream and river ecosystem functioning, one would expect these variables to be incorporated into stream and river assessment tools. Indeed, they have been but, in our opinion, to a very limited extent.

Some stream habitat assessment tools take into account the presence or the abundance of OM, and especially of LW. For instance, the IHF (Pardo et al., 2002), which is designed to assess habitat diversity of Mediterranean rivers and can score up to 100 points, gives up to 4 points to the cover of leaf litter and up to 2 additional points to the presence of logs and branches. On the other hand, the RHS (Raven et al., 1997) considers the abundance of LW, but the HQA, which is the tool derived to assess river condition, gives LW a maximum of 8 points from a total maximum of 100 points. Similarly, the US Rapid Bioassessment Protocols for Use in Streams and Wadeable Rivers (Barbour et al., 1999) consider LW cover, but lump it with other "epifaunal substrate", basically stable structures such as logs, rocks and undercut banks, in only one of the 10 elements it takes in account. Therefore, OM and LW seem not to be very prominent features of general habitat assessment protocols, probably because those who designed them were more concerned with other aspects of river habitats such as channelization or siltation.

Breakdown, on the other hand, has been by far the OM variable most often considered for assessment or diagnostic tools, probably because the seminal Gessner and Chauvet (2002) paper convinced breakdown scientist of the potential relevance of their work. In this context, the EU funded the research project RIVFUNCTION, whose aim was integrating ecosystem function (namely, OM breakdown) into river quality assessment and management, and there have been some national projects in the same line, such as IMPARIOS (Pozo et al., 2011). Some of these projects produced reasonably standardized protocols to measure OM breakdown, including 
leaves (Graça et al., 2005), sticks (Arroita et al., 2012), tea bags (Keuskamp et al., 2013), cellulose strips (Tiegs et al., 2013) and other materials (Kampfraath et al., 2012). Scientists have also developed a number of metrics to analyse and score results, such as the ratio of breakdown rate in a reach compared to a "reference" reach (Gessner \& Chauvet, 2002). Therefore, there is a broad range of techniques that can be adapted to a wide variety of environmental situations to assess ecosystem functioning. On the wrong side, breakdown rates have resulted to be highly variable among sites (Pérez et al., 2011), making it necessary to define clear reference conditions for each case.

Coupled to these technical developments, a number of large collaborative research papers showed clear patterns in breakdown following environmental gradients. For instance, Boyero et al. (2011) measured decomposition in 22 streams spanning a large latitudinal range, and found breakdown rate to increase but the relative contribution of detritivores to decrease with temperature. Similarly, Woodward et al. (2012), in a pan-European experiment, showed breakdown to respond to nutrient concentration following a hump shape, which they attributed to nutrients accelerating microbial activity at low to medium concentrations, decreasing the role of shredders at large concentrations. On the other hand, Aristi et al. (2012) measured the breakdown of tongue depressors at 66 sites across the Iberian Peninsula, spanning a very large range of contamination and other types of environmental degradation. They found 50-fold variations in breakdown rates, which were related to temperature, phosphorus, catchment area, water quality and riparian buffer width.

The above papers are encouraging examples of the possibility of using breakdown to assess stream and river functional impairment. Indeed, a large number of breakdown papers claimed their results to be meaningful for this purpose (e.g., Friberg et al., 2011; Hladyz et al., 2011; Lecerf \& Chauvet, 2008; Young et al., 2008). Despite all these claims, managers did not adopt breakdown tools for routine monitoring of river ecosystems, with notable exceptions such as the
Waikato Regional Council in New Zealand (Collier \& Hamer, 2014).

\section{CONCLUDING REMARKS}

Decades of research have made it clear that OM is a key element in streams and rivers, and its inputs, storage and breakdown are consequently pivotal ecosystem functions. Furthermore, today we have a clear understanding of the main environmental factors governing OM dynamics. As researchers produced an increasing volume of data, we have been able to progress from vague intuitions to the definition of clear patterns and the identification of some of the most important mechanisms behind these patterns. Equally important, researchers have narrowed down and clearly identified many of the remaining questions regarding $\mathrm{OM}$ in streams and rivers.

On the weak side, scientists have been little effective at convincing managers of the practical relevance of OM, and of the need to incorporate functional variables into river ecosystem assessment, as well as at putting streams and rivers in the global Carbon agenda. Rather than complaining about the little interest of managers into our scientific results, we should continue research to deepen in the mechanistic understanding of OMrelated processes, such as movement and breakdown, investigate the interactions between OM and pollutants, and continue gathering data on $\mathrm{OM}$ in reference and impaired sites. Only this information will allow scientists moving from description to prescription. Of particular importance is to take advantage of the research opportunities linked to ecosystem manipulation, such as measuring the effects of restoration projects, and to increase our interactions with managers and stakeholders. Only then will OM reach its real importance in river management.

\section{ACKNOWLEDGEMENTS}

This work has been supported by the EU $7^{\text {th }}$ Framework Programme Funding under Grant agreement no. 603629-ENV-2013-6.2.1-Globaqua. 


\section{REFERENCES}

ABBE, T. B. \& D. R. MONTGOMERY. 1996. Interaction of large woody debris, channel hydraulics and habitat formation in large rivers. Regulated Rivers, 12: 201-221.

ACUÑA, V., T. DATRY, J. MARSHALL, D. BARCELÓ, C. N. DAHM, A. GINEBREDA, G. MCGREGOR, S. SABATER, K. TOCKNER \& M. A. PALMER. 2014. Why should we care about temporary waterways? Science, 343: 1080-1081.

ALBERTS, J. M., SULLIVAN \& A. KAUTZA. 2013. Riparian swallows as integrators of landscape change in a multiuse river system: implications for aquatic-to-terrestrial transfer of contaminants. Science of the Total Environment, 463: 42-50.

ARISTI, A., J. R. DÍEZ, A. LARRAÑAGA, A. NAVARRO-ORTEGA, D. BARCELÓ \& A. ELOSEGI. 2012. Assessing the effects of multiple stressors on the functioning of Mediterranean rivers using poplar wood breakdown. Science of the Total Environment, 440: 272-279.

ARROITA, M., I. ARISTI, L. FLORES, A. LARRAÑAGA, J. R. DÍEZ, J. MORA, A. M. ROMANÍ $\&$ A. ELOSEGI. 2012. The use of wood sticks to assess stream ecosystem functioning: comparison with leaf breakdown rates. Science of the Total Environment, 440: 115-122.

ARTIGAS, J., A. M. ROMANÍ, A. GAUDES, I. MUNOZ \& S. SABATER. 2008. Organic matter availability structures microbial biomass and activity in a Mediterranean stream. Freshwater Biology, 54: 2025-2036.

ATTIWILL, P. M. \& M. A. ADAMS. 1993. Nutrient cycling in forests. New Phytologist, 124: 561-582.

BALDWIN, D. S., K. L. WHITWORTH \& C. L. HOKLEY. 2014. Uptake of dissolved organic carbon by biofilms provides insights into the potential impact of loss of large woody debris on the functioning of lowland rivers. Freshwater Biology, 59: 692-702.

BANO, N., M. A. MORAN \& R. E. HODSON. 1997. Bacterial utilization of dissolved humic substances from a freshwater swamp. Aquatic Microbial Ecology, 12: 233-238.

BARBOUR, M. T., J. GERRITSEN, B. D. SNYDER \& J. B. STRIBLING. 1999. Rapid Bioassessment Protocols for Use in Streams and Wadeable Rivers: Periphyton, Benthic Macroinvertebrates and Fish. $2^{\text {nd }}$ ed. EPA 841-B-99-002. US EPA, Office of Water, Washington D.C., USA.
BARROS, N., J. J. COLE , L. J. TRANVIK, Y. T. PRAIRIE, D. BASTVIKEN, V. L. M. HUSZAR, P. DEL GIORGIO \& F. ROLAND. 2011. Carbon emission from hydroelectric reservoirs linked to reservoir age and latitude. Nature Geosciences, 4: 593-596.

BASTVIKEN, D., L. J. TRANVIK, J. A. DOWNING, P. M. CRILL \& A. ENRICH-PRAST. 2011. Freshwater methane emissions offset the continental carbon sink. Science, 331: 50.

BATTIN, T. J., L. A. KAPLAN, J. D. NEWBOLD \& C. M. E. HANSEN. 2003. Contributions of microbial biofilms to ecosystem processes in stream mesocosms. Nature, 426: 439-442.

BATTIN, T. J., L. A. KAPLAN, S. FINDLAY, C. S. HOPKINSON, E. MARTÍ, A. I. PACKMAN, J. D. NEWBOLD \& F. SABATER. 2009. Biophysical controls on organic carbon fluxes in fluvial networks. Nature Geoscience, 1: 95-100.

BAXTER, C. V., K. D. FAUSCH, M. MURAKAMI \& P. L. CHAPMAN. 2004. Fish invasion restructures stream and forest food webs by interrupting reciprocal prey subsidies. Ecology, 85: 2656-2663.

BECKMAN, N. D. \& E. WOHL. 2014. Carbon storage in mountainous headwater streams: The role of old-growth forest and logjams. Water Resources Research, 50: 2376-2393.

BERNHARDT, E. S., G. E. LIKENS, D. C, BUSO \& C. T. DRISCOLL. 2003. In-stream uptake dampens effects of major forest disturbance on watershed nitrogen export. Proceedings of the National Academy of Sciences, 100: 10304-10308.

BERNHARDT, E. S., M. A. PALMER, J. D. ALLAN, R. ABELL, G. ALEXANDER, S. BROOKS, J. CARR, S. CLAYTON, C. H. DAHM, J. FOLLSTAD SHAH, D. L. GALAT, S. GLOSS, P. GOODWIN, D. J. HART, B. HASSETT, R. JENKINSON, S. KATZ, G. M. KONDOLF, P. S. LAKE, R. LAVE, J. L. MEYER, T. K. O'DONNELL, L. PAGANO \& E. SUDDUTH. 2005a. Synthesizing U.S. river restoration efforts. Science, 308: 636637.

BERNHARDT, E. S., G. E. LIKENS, R. O. HALL, D. C. BUSO, S. G. FISHER, T. M. BURTON, J. L. MEYER, W. H. MCDOWELL, M. S. MAYER, W. B. BOWDEN, S. E. G. FINDLAY, K. H. MACNEALE, R. S. STELZER \& W. H. LOWE. 2005b. Can't see the forest for the stream? Instream processing and terrestrial nitrogen exports. BioScience, 55: 219-230. 
BOIVIN, M., T. BUFFIN-BELANGER \& H. PIEGAY. 2015. The raft of the Saint-Jean River, Gaspe (Quebec, Canada): A dynamic feature trapping most of the wood transported from the catchment. Geomorphology, 231: 270-280.

BONIN, H. L., R. P. GRIFFITHS \& B. A. CALDWELL. 2000. Nutrient and microbiological characteristics of fine benthic organic matter in mountain streams. Journal of the North American Benthological Society, 19: 235-249.

BOULTON, A. J. \& J. G. FOSTER. 1998. Effects of buried leaf litter and vertical hydrologic exchange on hyporheic water chemistry and fauna in a gravel-bed river in northern New South Wales, Australia. Freshwater Biology, 40: 229-243.

BOYER, K. L., D. R. BERG \& S. V. GREGORY. 2003. Riparian management for wood in rivers. In: The ecology and management of wood in World rivers. S. V. Gregory, K. L. Boyer \& A. M. Gurnell (eds.): 407-420. American Fisheries Society. Bethesda, MD. USA.

BOYERO, L., R. G. PEARSON, M. O. GESSNER, L. A. BARMUTA, V. FERREIRA, M. A. S. GRAÇA, D. DUDGEON, A. J. BOULTON, M. CALLISTO, E. CHAUVET, J. E. HELSON, A. BRUDER, R. J. ALBARIÑO, C. M. YULE, M. ARUNACHALAM, J. N. DAVIES, R. FIGUEROA, A. S. FLECKER, A. RAMÍREZ, R. G. DEATH, T. IWATA, J. M. MATHOOKO, C. MATHURIAU, J. F. GONÇALVES JR, M. S. MORETTI, T. JINGGUT, S. LAMOTHE, C. M'ERIMBA, L. RATNARAJAH, M. H. SCHINDLER, J. CASTELA, L. M. BURIA, A. CORNEJO, V. DIAZ VILLANUEVA \& D. C. WEST. 2011. A global experiment suggests climate warming will not accelerate litter decomposition in streams but might reduce carbon sequestration. Ecology Letters, 14: 289-294.

BROOKS, A. P. 2006. Design guideline for the reintroduction of wood into Australian streams. Land \& Water Australia, Canberra.

BUNDSCHUH, M. \& B. G. McKIE. 2015. An ecological and ecotoxicological perspective on fine particulate organic matter in streams. Freshwater Biology, DOI: 10.1111/fwb.12608.

CANHOTO, C. \&. M. A. S. GRAÇA. 1995. Food value of introduced eucalypt leaves for a Mediterranean stream detritivore -Tipula lateralis. Freshwater Biology, 34: 209-214.

CASAS, J. J., A. LARRAÑAGA, M. MENÉNDEZ, J. POZO, A. BASAGUREN, A. MARTÍNEZ, J. PÉREZ, J. M. GONZÁLEZ, C. CASADO, E.
DESCALS, N. ROBLAS, J. A. LOPÉZ-GONZÁLEZ \& J. L. VALENZUELA. 2013. Leaf-litter decomposition of native and introduced tree species of contrasting quality in headwater streams: How does the regional setting matter? Science of the Total Environment, 458-460: 197-208.

CHAPMAN, P. M., F. WANG, C. JANSSEN, G. PERSOONE \& H. E. ALLEN. 1998. Ecotoxicology of metals in aquatic sediments: binding and release, bioavailability, risk assessment, and remediation. Canadian Journal of Fisheries and Aquatic Sciences, 55: 221-2243.

COLLIER, K. J. \& J. N. HALLIDAY. 2000. Macroinvertebrate-wood associations during decay of plantation pine in New Zealand pumice-bed streams: stable habitat or trophic subsidy? Journal of the North American Benthological Society, 19: 91-111.

COLLIER, K. J. \& M. P. HAMER. 2014. Aquatic invertebrate communities and functional indicators along the lower Waikato River. Waikato Regional Council Technical Report 2014/02. Waikato Regional Council. Hamilton. NZ.

CORENBLIT, D., E. TABACCHI, J. STEIGER \& A. M. GURNELL. 2007. Reciprocal interactions and adjustments between fluvial landforms and vegetation dynamics in river corridors: A review of complementary approaches. Earth-Science Reviews, 84: 56-86.

DÍEZ, J. R., A. ELOSEGI \& J. POZO. 2001. Woody debris in north Iberian streams: Influence of geomorphology, vegetation and management. Environmental Management, 28: 687-698.

DOBSON, M., A. G. HILDREW, S. ORTON \& S. J. ORMEROD. 1995. Increasing litter retention in moorland streams: ecological and management aspects of a field experiment. Freshwater Biology, 33: 325-337.

DOONG, D. J., H. C. CHUANG, C. L. SHIEH \& J. H. HU. 2011. Quantity, distribution, and impacts of coastal driftwood triggered by a typhoon. Marine Pollution Bulletin, 62: 1446-1454.

EGGLETON, J. \& K. V. THOMAS. 2004. Factors affecting the release and bioavailability of contaminants during sediment disturbance events. Environmental International, 30: 973-980.

EHRMAN, T. P. \& G. A. LAMBERTI. 1992. Hydraulic and particulate matter retention in a $3^{\text {rd }}$ order Indiana stream. Journal of the North American Benthological Society, 11: 341-349. 
ELOSEGI, A \& L. B. JOHNSON. 2003. Wood in streams and rivers in developed landscapes. In: The ecology and management of wood in World rivers. S. V. Gregory, K. L. Boyer \& A. M. Gurnell (eds.): 337-354. American Fisheries Society. Bethesda, MD, USA.

ELOSEGI, A., J. R. DÍEZ \& J. POZO. 2007. Contribution of dead wood to the carbon flux in forested streams. Earth Surface Processes and Landforms, 32: 1219-1228.

ELOSEGI, A., J. R. DÍEZ, L. FLORES \& J. MOLINERO. 2016. Pools, channel form and sediment retention in wood-restored streams: potential effects on downstream reservoirs. Geomorphology, DOI: 10.1016/j.geomorph.2016.01.007.

FERREIRA, V. \& C. CANHOTO. 2014. Effect of experimental and seasonal warming on litter decomposition in a temperate stream. Aquatic Sciences, 76: $15-163$.

FERREIRA, V., A. LARRAÑAGA, V. GULIS, A. BASAGUREN, A. ELOSEGI, M. A. S. GRAÇA \& J. POZO. 2015. The effect of eucalypt plantations on plant litter decomposition and macroinvertebrate communities in Iberian streams. Forest Ecology and Management, 335: 129-138.

FERREIRA, V., J. KORICHEVA, J. POZO \& M. A. S. GRAÇA. 2016. A meta-analysis on the effects of changes in the composition of native forests on litter decomposition in streams. Forest Ecology and Management, 364: 27-38.

FIEBIG, D. M. 1992. Fates of dissolved free amino acids in groundwater discharged through stream bed sediments. Hydrobiologia, 235/236: 311-319.

FISHER, S. G. \& G. E. LIKENS. 1972. Stream ecosystem: organic energy budget. BioScience, 22: 33-35.

FLORES, L., A. LARRANAGA, J. R. DIEZ \& A. ELOSEGI. 2011. Experimental wood addition in streams: effects on organic matter storage and breakdown. Freshwater Biology, 56: 2156-2167.

FLORES, L., J. R. DÍEZ, A. LARRAÑAGA, C. PASCOAL \& A. ELOSEGI. 2013. Effects of retention site on breakdown of organic matter in a mountain stream. Freshwater Biology, 58: 1267-1278.

FORNASINI, E. 1991. A 2-D systems approach to river pollution modelling. Multidimensional Systems and Signal Processing, 2: 233-265.

FRIBERG, N., N. BONADA, D. C. BRADLEY, M. J. DUNBAR, F. K. EDWARDS, J. GREY, R. B. HAYES, A. G. HILDREW, N. LAMOUROUX, M.
TRIMMER \& G. WOODWARD. 2011. Biomonitoring of human impacts in freshwater ecosystems: The good, the bad and the ugly. Advances in Ecological Research, 44: 1-68.

GAUDES, A., J. ARTIGAS, A. M. ROMANÍ, S. SABATER \& I. MUÑOZ. 2009. Contribution of microbial and invertebrate communities to leaf litter colonization in a Mediterranean stream. Journal of the North American Benthological Society, 28: 34-43.

GEISSEN, V., H. MOL, E. KLUMPP, G. UMLAUF, M. NADAL, M. VAN DER PLOEG, S. E. A. T. M. VAN DE ZEE \& C. J. RITSEMA. 2015. Emerging pollutants in the environment: A challenge for water resource Management. International Soil and Water Conservation Research, 3: 57-65.

GESSNER, M. O. \& E. CHAUVET. 2002. A case for using litter breakdown to assess functional stream integrity. Ecological Applications, 12: 498-510.

GOSZ, J. R., G. E. LIKENS \& F. H. BORMANN. 1973. Nutrient release from decomposing leaf and branch litter in the Hubbard Brook Forest, New Hampshire. Ecological Monographs, 43: 173-191.

GRAÇA, M. A. S., F. BÄRLOCHER \& M. O. GESSNER (eds.). 2005. Methods to study litter decomposition: a practical guide. Springer, Dordrecht, Holland.

GRANIER, L. K., P. LAFRANCE \& P. G. C. CAMPBELL. 1999. An experimental design to probe the interactions of dissolved organic matter and xenobiotics: bioavailability of pyrene and 2,2',5,5'-tetrachlorobiphenyl to Daphnia magna. Chemosphere, 38: 335-350.

GRATTON, C., J. DONALDSON \& M. J. VANDER ZANDEN. 2008. Ecosystem linkages between lakes and the surrounding terrestrial landscape in Iceland. Ecosystems, 11: 764-774.

GREGORY, S. V., K. L. BOYER \& A. M. GURNELL (eds). 2003. The ecology and management of wood in World rivers. American Fisheries Society, Symposium 37. Bethesda, MD. USA.

GROS, M., M. PETROVIC \& D. BARCELÓ. 2007. Wastewater treatment plants as a pathway for aquatic contamination by pharmaceuticals in the Ebro river basin (northeast Spain). Environmental Toxicology and Chemistry, 26: 1553-1562.

GUIBAUD, G., C. GAUTHIER \& J. AYELE. 2000. Role of natural organic matter in the mobility of aluminium ions in rivers in the Limousin region (France). Agronomie, 20: 577-590. 
GULIS, V. \& K. SUBERKROPP. 2003. Leaf litter decomposition and microbial activityin nutrientenriched and unaltered reaches of a headwater stream. Freshwater Biology, 48: 123-134.

GURNELL, A. M. , G. E. PETTS, D. M. HANNAH, B. P. G. SMITH, P. J. EDWARDS, J. KOLLMANN, J. V. WARD \& K. TOCKNER. 2000. Wood storage within the active zone of a large European gravel-bed river. Geomorphology, 34: $55-72$.

GURNELL, A. M. , G. E. PETTS, D. M. HANNAH, B. P. G. SMITH, P. J. EDWARDS, J. KOLLMANN, J. V. WARD \& K. TOCKNER. 2001. Riparian vegetation and island formation along the gravel-bed Fiume Tagliamento, Italy. Earth Surface Processes and Landforms, 26: 31-62.

HALL, R. O. \& J. L. MEYER. 1998. The trophic significance of bacteria in a detritus-based stream food web. Ecology, 79: 1995-2012.

HARMON, M. E., J. F. FRANKLIN, F. J. SWANSON, P. SOLLINS, S. V. GREGORY, J. D. LATTIN, N. H. ANDERSON, S. P. CLINE, N. G. AUMEN, J. R. SEDELL, G. W. LIENKAEMPER, K. CROMACK Jr \& K. W. CUMMINS. 1986. Ecology of coarse woody debris in temperate ecosystems. Advances in Ecological Research, 15: 133302.

HARPER, D. M. 1992. Eutrophication of freshwaters. Principles, problems and restoration. Chapman \& Hall, London.

HELFIELD, J. M. \& R. J. NAIMAN. 2006. Keystone interactions: Salmon and bear in riparian forests of Alaska. Ecosystems, 9: 167-180.

HIEBER, M. \& M. O. GESSNER. 2002. Contribution of stream detrivores, fungi, and bacteria to leaf breakdown based on biomass estimates. Ecology 83: 1026-38.

HILL, A. R. 1996. Nitrate removal in stream riparian zones. Journal of Environmental Quality, 25: 743755.

HILL, B. H. \& J. R. WEBSTER. 1983. Aquatic macrophyte contribution to the New River organic matter budget. In: Dynamics of lotic ecosystems. T. Fontaine \& S. Bartell (eds): 273-282. Ann Arbor Science. Michigan.

HLADYZ, S., K. ÅBJÖRNSSON, E. CHAUVET, M. DOBSON, A. ELOSEGI, V. FERREIRA, T. FLEITUCH, M. O. GESSNER, P. S. GILLER, V. GULIS, S. A. HUTTON, J. LACOURSIERE, S. LAMOTHE, A. LECERF, B. MALMQVIST, B. G. MCKIE, M. NISTORESCU, E. PREDA, M. P.
RIIPINEN, G. RISNOVEANU, M. SCHINDLER, S. D. TIEGS, L .B. M. VOUGHT \& G. WOODWARD. 2011. Stream ecosystem functioning in an agricultural landscape: the importance of terrestrial-aquatic linkages. Advances in Ecological Research, 44: 211-276.

HOLOMUZKI, J. R. \& J. D. HOYLE. 1990. Effect of predatory fish presence on habitat use and diel movement of the stream amphipod Gammarus minus. Freshwater Biology, 24: 509-517.

HUNT, R. L. 1993. Trout stream therapy. University of Winsconsin Press, Madison.

HYATT, T. L. \& R. J. NAIMAN. 2001. The residence time of large woody debris in the Queets River, Washington, USA. Ecological Applications, 11: 191-202.

IPCC. 2007. Summary for policymakers. In: Climate Change 2007: The Physical Science Basis. Contribution of Working Group I to the Fourth Assessment Report of the Intergovernmental Panel on Climate Change. S. Solomon, D. Qin, M. Manning, Z. Chen, M. Marquis, K. B. Averyt, M. Tignor \& H. L. Miller (eds.): 539-543. Cambridge University Press, Cambridge, UK.

JOHNSON, L. T., J. L. TANK, R. O. HALL, P. J. MULHOLLAND, S. K. HAMILTON, H. M. VALETT, J. R. WEBSTER, M. J. BERNOT, W. H. MCDOWELL, B. J. PETERSON \& S. M. THOMAS. 2013. Quantifying the production of dissolved organic nitrogen in headwater streams using ${ }^{15} \mathrm{~N}$ tracer additions. Limnology \& Oceanography, 58: 1271-1285.

JONES, J. B., Jr. \& L. A. SMOCK. 1991. Transport and retention of particulate organic matter in two low-gradient headwater streams. Journal of the North American Benthological Society, 10: 115-126.

JOYCE, P. \& R. S. WOTTON. 2008. Shredder fecal pellets as stores of allochthonous organic matter in streams. Journal of the North American Benthological Society, 27: 521-528.

KAIL, J., D.HERING, S. MUHAR, M. GERHARD \& S. PREIS. 2007. The use of large wood in stream restoration: experiences from 50 projects in Germany and Austria. Journal of Applied Ecology, 44: 1145-1155.

KALBITZ, K. \& R. WENNRICH. 1998. Mobilization of heavy metals and arsenic in polluted wetland soils and its dependence on dissolved organic matter. The Science of the Total Environment, 209: 2739. 
KAMPFRAATH, A. A., E. R. HUNTING, C. MULDER, A. M. BREURE, M. O. GESSNER, M. H. S. KRAAK \& W. ADMIRAAL. 2012. DECOTAB: a multipurpose standard substrate to assess effects of litter quality on microbial decomposition and invertebrate consumption. Freshwater Science, 31: $1156-1162$.

KAPLAN, L. A. \& T. L. BOTT. 1989. Diel fluctuations in bacterial activity on streambed substrata during vernal algal blooms: effects of temperature, water chemistry, and habitat. Limnology \& Oceanography, 34: 718-733.

KARICKHOFF, S. W., D. S. BROWN \& T. A. SCOTT. 1979. Sorption of hydrophobic pollutants on natural sediments. Water Research, 13: 241-248.

KARLSSON, O. M., J. S. RICHARDSON \& P. A. KIFFNEY. 2005. Modelling organic matter dynamics in headwater streams of south-western British Columbia, Canada. Ecological Modelling, 183: 463-476.

KAUSHIK, N. K. \& H. B. N. HYNES. 1971. Fate of dead leaves that fall into streams. Archiv fuir Hydrobiologie, 68: 465-515.

KAUTZA, A. \& S. M. P. SULLIVAN. 2015. Shifts in reciprocal river-riparian arthropod fluxes along an urban-rural landscape gradient. Freshwater Biology, 60: 2156-2168.

KELLER, E. A. \& F. J. SWANSON. 1979. Effects of large organic material on channel form and fluvial processes. Earth Surface Processes, 4: 361-380.

KELLY, M. G. \& B. A. WHITTON. 1995. The trophic diatom index: a new index for monitoring eutrophication in rivers. Journal of Applied Phycology, 7: 433-444.

KEMP, J. L., D. M. HARPER \& G. A. CROSA. 2000. The habitat-scale ecohydraulics of rivers. Ecological Engineering, 16: 17-29.

KENDALL, C., S. R. SILVA \& V. J. KELLY. 2001. Carbon and nitrogen isotopic compositions of particulate organic matter in four large river systems across the United States. Hydrological Processes, 15: 1301-1346.

KEUSKAMP, J. A., B. J. J. DINGEMANS, T. LEHTINEN, J. M. SAMEEL \& M. M. HEFTING. 2013. Tea Bag Index: a novel approach to collect uniform decomposition data across ecosystems. Methods in Ecology and Evolution, 4: 10701075 .
KIM, H. S., K. S. LINDSAY \& F. K. PFAENDER. 2008. Enhanced mobilization of field contaminated soil-bound PAHs to the aqueous phase under anaerobic conditions. Water, Air and Soil Pollution, 189: 135-147.

KNOWLES, R. 1982. Denitrification. Microbiological Reviews, 46: 43-70.

LAMBERTSON, L. \& M. NILSSON. 2006. Organic material: The primary control on mercury methylation and ambient methyl mercury concentrations in estuarine sediments. Environmental Science and Technology, 40: 1822-1829.

LANGE-BERTALOT, H. 1979. Pollution tolerance as a criterion for water quality estimation. Nova Hedwigia, 64: 285-304.

LARRAÑAGA, S., J. R. DÍEZ, A. ELOSEGI \& J. POZO. 2003. Leaf retention in streams of the Agüera basin (northern Spain). Aquatic Sciences, 65: 158-166.

LARRAÑAGA, A., S. LARRAÑAGA, A. BASAGUREN, A. ELOSEGI \& J. POZO. 2006. Assessing impact of eucalyptus plantations on benthic macroinvertebrate communities by a litter exclusion experiment. Annales de Limnologie. International Journal of Limnology, 42: 1-8.

LECERF, A. \& E. CHAUVET. 2008. Diversity and functions of leaf-decaying fungi in human-altered streams. Freshwater Biology, 53: 1658-1672.

LEGENDRE, L. \& F. RASSOULZADEGAN. 1995. Plankton and nutrient dynamics in marine waters. Ophelia, 41: 153-172.

LEPORI, F., D. PALM \& B. MALMQVIST. 2005. Effects of stream restoration on ecosystem functioning: detritus retentiveness and decomposition. Journal of Applied Ecology, 42: 228-238.

LIÉBAULT, F. \& H. PIÉGAY. 2002. Causes of $20^{\text {th }}$ century narrowing in mountain and piedmont rivers and streams of south-eastern France. Earth Surface Processes and Landforms, 27: 425-444.

LIN, L. \& J. R. WEBSTER. 2014. Detritus decomposition and nutrient dynamics in a forested headwater stream. Ecological Modelling, 293: 58-68.

LOBECK, A. K. 1939. Geomorphology. Mc Graw Hill, New York.

LOOS, R., B. M. GAWLIK, G. LOCORO, E. RIMAVICIUTE, S. CONTINI \& G. BIDOGLIO. 2009. EU-wide survey of polar organic persistent pollutants in European river waters. Environmental Pollution, 157: 561-568.

LUCÍA, A., F. COMITI, M. BORGA, M. CAVALLI \& L. MARCHI. 2015. Dynamics of large wood 
during a flash flood in two mountain catchments. Natural Hazards Earth System Science, 15: 17411755.

MANERKAR, M. A., S. SEENA \& F. BÄRLOCHER. 2008. Q-RT-PCR for assessing archaea, bacteria, and fungi during leaf decomposition in a stream. Microbial Ecology, 56: 467-473.

MARCARELLI, A. M., C. V. BAXTER, M. M. MINEAU \& R. O. HALL. 2011. Quantity and quality: unifying food web and ecosystem perspectives on the role of resource subsidies in freshwaters. Ecology, 92: 1215-1225.

MELILLO, J. M., R. J. NAIMAN, J. D. ABER \& A. E. LINKINS. 1984. Factors controlling mass-loss and nitrogen dynamics of plant litter decaying in northern streams. Bulletin of Marine Science, 35: 341-356.

MOLINERO, J. \& J. POZO. 2004. Impact of a eucalyptus (Eucalyptus globulus Labill.) plantation on the nutrient content and dynamics of coarse particulate organic matter (CPOM) in a small stream. Hydrobiologia, 528: 143-165.

MOLINERO, J. \& J. POZO, 2006. Organic matter, nitrogen and phosphorus fluxes associated with leaf litter in two small streams with different riparian vegetation: a budget approach. Archiv für Hydrobiologie, 166: 363-385.

MOLINERO, J., J. POZO \& E. GONZÁLEZ. 1996. Litter breakdown in streams of the Agüera catchment: Influence of dissolved nutrients and land use. Freshwater Biology, 36: 745-756.

MOORE, J. C., E. L. BERLOW, D. C. COLEMAN, P. C. DE RUITER, Q. DONG, A. HASTINGS, N. C. JOHNSON, K. S. MCCANN, K. MELVILLE, P. J. MORIN, K. NADELHOFFER, A. D. ROSEMOND, D. M. POST, J. L. SCOW, M. J. VANNI \& D. H. WALL. 2004. Detritus, trophic dynamics and biodiversity. Ecology Letters, 7: 584-600.

MULHOLLAND, P. J. 1992. Regulation of nutrient concentrations in a temperate forest stream: Roles of upland, riparian, and instream processes. Limnology \& Oceanography, 37: 1512-1526.

MULHOLLAND, P. J., J. D. NEWBOLD, J. W. ELWOOD, L. A. FERREN \& J. R. WEBSTER. 1985. Phosphorus spiralling in a woodland stream: seasonal variations. Ecology, 66: 1012-1023.

NAKAMURA, F. \& F. J. SWANSON. 1993. Effects of coarse woody debris on morphology and sediment storage of a mountain stream system in Western Oregon. Earth Surface Processes and Landforms, 18: 43-61.
NAKANO, S. \& M. MURAMAKI. 2001. Reciprocal subsidies: dynamic interdependence between terrestrial and aquatic food webs. Proceedings of the National Academy of Sciences, 98: 166-170.

NAMIHIRA, A., H. KOBAYASHI, K. TAKAKI \& M. GOTO. 2009, Experimental study on basic shape of simple device for prevention of inflow and accumulation of buoyant refuse at the intake of headworks, Transaction of the Japanese Society of Irrigation, Drainage and Rural Engineering, 77: 453460.

NIYOGI, D. K., W. M. LEWIS, JR. \& D. M. MCKNIGHT. 2001. Litter breakdown in mountain streams affected by acid mine drainage: biotic mediation of abiotic controls. Ecological Applications, 11: 506-516.

OPPERMAN, J., A. MERENDLENDER \& D. LEWIS. 2006. Maintaining wood in streams: A vital action for fish conservation. University of California. Oakland, California.

PAL, A., K. Y. H. GIN, A. Y. C. LIN \& M. REINHARD. 2010. Impacts of emerging organic contaminants on freshwater resources: Review of recent occurrences, sources, fate and effects. Science of the Total Environment, 408: 6062-6069.

PALMER, M. A., H. L. MENNINGER \& E. BERNHARDT. 2010. River restoration, habitat heterogeneity and biodiversity: a failure of theory or practice? Freshwater Biology, 55: 205-222.

PARDO, I., M. ALVAREZ, J. J. CASAS, J. L. MORENO, S. VIVAS, N. BONADA, J. ALBATERCEDOR, P. JÁIMEZ-CUÉLLAR, G. MOYÀ, N. PRAT, S. ROBLES, M. L. SUÁREZ, M. TORO \& M. R. VIDAL-ABARCA. 2002. El hábitat de los ríos mediterráneos. Diseño de un índice de diversidad de hábitat. Limnetica, 21: 115-133.

PÉREZ, J., M. MENÉNDEZ, S. LARRAÑAGA \& J. POZO. 2011. Inter- and intra-regional variability of leaf litter breakdown in reference headwater streams of northern Spain: Atlantic versus Mediterranean streams. International Review of Hydrobiology, 96: 105-117.

PETERSEN, R. C. \& K. W. CUMMINS. 1974. Leaf processing in a woodland stream. Freshwater Biology, 4: 343-368.

PETROVIC, M., A. GINEBREDA, I. MUÑOZ \& D. BARCELÓ. 2013. The river drugstore: The treats of emerging pollutants to river conservation. In: River conservation: challenges and opportunities. S. Sabater \& A. Elosegi A (eds.): 105-126. Fundación BBVA, Bilbao. 
PIÉGAY, H. \& A. M. GURNELL. 1997. Large woody debris and river geomorphological pattern. Examples from SE France and S England. Geomorphology, 19: 99-116.

PIÉGAY, H., K. J. GREGORY, V. BONDAREV, A. CHIN, N. DAHLSTROM, A. ELOSEGI, S. V. GREGORY, V. JOSHI, M. MUTZ, M. RINALDI, B. WYZGA \& J. ZAWIEJSKA. 2005. Public perception as a barrier to introducing wood in rivers for restoration purposes. Environmental Management, 36: 665-674.

PONSATÍ, L., V. ACUÑA, I. ARISTI, M. ARROITA, E. GARCÍA-BERTHOU, D. VON SCHILLER, A. ELOSEGI \& S. SABATER. 2014. Biofilm responses to flow regulation by dams in Mediterranean rivers. River Research \& Applications, DOI: 10.1002/rra.2807.

POZO, J. 2005. Coarse particulate organic matter budgets. In: Methods to study litter decomposition: a practical guide. M. A. S. Graça, F. Bärlocher \& M. O. Gessner (eds.): 43-50. Springer, Dordrecht, Holland.

POZO, J., E. GONZÁLEZ, J. R. DÍEZ, J. MOLINERO \& A. ELÓSEGUI. 1997. Inputs of particulate organic matter to streams with different riparian vegetation. Journal of the North American Benthological Society, 16: 602-611.

POZO, J., A. BASAGUREN, A ELÓSEGUI, J. MOLINERO, E. FABRE \& E. CHAUVET. 1998. Afforestation with Eucalyptus globulus and leaf litter decomposition in streams of northern Spain. Hydrobiologia 373/374: 101-109.

POZO, J., J. J. CASAS, M. MENÉNDEZ, S. MOLLÁ, I. AROSTEGUI, A. BASAGUREN, C. CASADO, E. DESCALS, J. GARCÍA-AVILÉS, J. M. GONZÁLEZ, A. LARRAÑAGA, E. LÓPEZ, M. LUSI, O. MOYA, J. PÉREZ, T. RIERA \& M. J. SALINAS. 2011. Leaf-litter decomposition in headwater streams: a comparison of the process among four climatic regions. Journal of the American Benthological Society, 30: 935-950.

QUINN, J. M., N. R. PHILLIPS \& S. M. PARKYN. 2007. Factors influencing retention of coarse particulate organic matter in streams. Earth Surface Processes and Landforms, 32: 1186-1203.

RAVEN, P. J., P. FOX, M. EVERARD, N. T. H. HOLMES \& F. W. DAWSON. 1997. River Habitat Survey: a new system for classifying rivers according their habitat quality. In: Freshwater quality: Defining the indefinable? J. P. Boon \& D.
L. Howell (eds.): 215-234. The Stationery Office, Edinburgh.

REDMAN, A. D., D. L. MACALADY \& D. AHMANN. 2002. Natural organic matter affects arsenic speciation and sorption onto hematite. Environmental Science and Technology, 36: 28892896.

RICHARDSON, J. S. 1991. Seasonal food limitation of detritivores in a montane stream -An experimental test. Ecology, 72: 873-887.

ROBERTS, B. J., P. J. MULHOLLAND \& J. N. HOUSER. 2007. Effects of upland disturbance and instream restoration on hydrodynamics and ammonium uptake in headwater streams. Journal of the North American Benthological Society, 26: $38-53$.

RONI, P., T. BEECHIE, G. PESS \& K. HANSON. 2015. Wood placement in river restoration: fact, fiction, and future direction. Canadian Journal of Fisheries \& Aquatic Sciences, 72: 466-478.

RUIZ-VILLANUEVA, V., J. M. BODOQUE, A. DÍEZ-HERRERO \& E. BLADÉ. 2014. Large wood transport as significant influence on flood risk in a mountain village. Natural Hazards, 74: 967-987.

RUNCK, C. 2007. Macroinvertebrate production and food web energetics in an industrially contaminated stream. Ecological Applications, 17: 740753.

SCEALY, J. A., S. J. MIKA \& A. J. BOULTON. 2007. Aquatic macroinvertebrate communities on wood in an Australian lowland river: experimental assessment of the interactions of habitat, substrate complexity and retained organic matter. Marine and Freshwater Research, 58: 153-165.

SCHULZE, T., S. WEISS, E. SCHYMANSKI, P. C. VON DER OHE, M. SCHMITT-JANSEN, R. ALTENBURGER, G. STRECK \& W. BRACK. 2010. Identification of a phytotoxic photo-transformation product of diclofenac using effect-directed analysis. Environmental Pollution, 158: 1461-1466.

SMOCK, L. A. 1990. Spatial and temporal variation in organic-matter storage in low-gradient, headwater streams. Archiv für Hydrobiologie, 118: 169184.

SOUNTHARARAJAH, D. P., P. LOGANATHAN, J. KANDASAMY \& S. VIGNESWARAN. 2015. Effects of humic acid and suspended solids on the removal of heavy metals from water by adsorption onto granular activated carbon. International Jour- 
nal of Environmental Research and Public Health, 12: $14075-10489$.

STANKUS, D. P., S. E. LOHSE, J. E. HUTCHINSON \& J. A. NASON. 2011. Interactions between natural organic matter and gold nanoparticles stabilized with different organic capping agents. Environmental Science and Technology, 45: 32383244.

SUlLIVAN, A. B., D. M. SNYDER \& S. A. ROUNDS. 2010. Controls on biochemical oxygen demand in the upper Klamath River, Oregon. Chemical Geology, 269: 12-21.

TANK, J. L., E. J.ROSI-MARSHALL, N. A. GRIFFITHS, S. A. ENTREKIN \& M. L. STEPHEN. 2010. A review of allochthonous organic matter dynamics and metabolism in streams. Journal of the North American Benthological Society, 29:118-146.

TIEGS, S. D., P. S. LEVI, J. RÜEGG, D. T. CHALONER, J. L. TANK \& G. A. LAMBERTI. 2011. Ecological effects of live salmon exceed those of carcasses during an annual spawning migration. Ecosystems, 14: 598-614.

TIEGS, S. D., J. E. CLAPCOTT, N. A. GRIFFITHS \& A. J. BOULTON. 2013. A standardized cottonstrip assay for measuring organic-matter decomposition in streams. Ecological Indicators, 32: 131139.

TSUI, M. T. K., J. C. FINLAT \& E. A. NATER. 2008. Effects of stream water chemistry and tree species on release and methylation of mercury during litter decomposition. Environmental Science and Technology, 42: 8692-8697.

VANNOTE, R. L., G. W. MINSHALL, K. W. CUMMINS, J. R. SEDELL, J. R. \& C. E. CUSHING. 1980. The River Continuum Concept. Canadian Journal of Fisheries and Aquatic Sciences, 37: 130-137.

VON SCHILLER, D., R. MARCÉ, B. OBRADOR, L. GÓMEZ, J. P. CASAS, V. ACUÑA \& M. KOSCHORRECK. 2014. Carbon dioxide emissions from dry watercourses. Inland Waters, 4: 377-382.

WALLACE, T. A., G. G. GANF \& J. D. BROOKES. 2008. A comparison of phosphorus and DOC leachates from different types of leaf litter in an urban environment. Freshwater Biology, 53: 1902-1913.

WALLACE, J. B., S. L. EGGERT, J. L. MEYER \& J. R. WEBSTER. 1997. Multiple trophic levels of a forest stream linked to terrestrial litter inputs. Science, 277: 102-104.
WEBSTER, J. R., S. W. GOLLADAY, E. F. BENFIELD, D. J. D'ANGELO \& G. T. PETERS. 1990. Effects of forest disturbance on particulate organic matter budgets of small streams. Journal of the North American Benthological Society, 9: 120140.

WEBSTER, J. R. \& J. L. MEYER. 1997. Organic matter budgets for streams: a synthesis. Journal of the North American Benthological Society, 16: 141-161.

WEBSTER, J. R., P. J. MULHOLLAND, J. L. TANK, H. M. VALETT, W. K. DODDS, B. J. PETERSON, W. B. BOWDEN, C. N. DAHM, S. FINDLAY, S. V. GREGORY, N. B. GRIMM, S. K. HAMILTON, S. L. JOHNSON, E. MARTÍ, W. H. MCDOWELL, J. L. MEYER, D. D. MORRALL, S. A. THOMAS \& W. M. WOLLHEIM. 2003. Factors affecting ammonium uptake in streams -an inter-biome perspective. Freshwater Biology, 48: 1329-1352.

WHITTAKER, R. H., G. E. LIKENS, F. H. BORMANN, J. S. EASTON \& T. G. SICCAMA. 1979. The Hubbard Brook Ecosystem Study: Forest nutrient cycling and element behavior. Ecology, 60: 203-220.

WIPFLI, M. S., J. P. HUDSON, J. P. CAOUETTE, N. L. MITCHELL, J. L. LESSARD, R. A. HEINTZ \& D. T. CHALONER. 2010. Salmon carcasses increase stream productivity more than inorganic fertilizer pellets: a test on multiple trophic levels in streamside experimental channels. Transactions of the American Fisheries Society, 139: 824-839.

WOHL, E. 2014. A legacy of absence: wood removal in US rivers. Progress in Physical Geography, 38: 637-663.

WOODWARD, G., M. O. GESSNER, P. S. GILLER, V. GULIS, S. HLADYZ, A. LECERF, B. MALMQVIST, B. G. MCKIE, S. D. TIEGS, H. CARISS, M. DOBSON, A. ELOSEGI, V. FERREIRA, M. A. S. GRAÇA, T. FLEITUCH, J. LACOURSIERE, M. NISTORESCU, J. POZO, G. RISNOVEANU, M. SCHINDLER, A. VADINEANU, L. B. M. VOUGHT \& E. CHAUVET. 2012. Continental-scale effects of nutrient pollution on stream ecosystem functioning. Science, 336: 1438-1440.

WU, T. R., H. WANG, Y. Y. KO, J. S. HSIEH, C. H. CHEN, C. LIN, C. YUE \& M. H. CUANG. Forensic diagnosis on flood-induced bridge failure. II: Framework of quantitative assessment. Journal 
of Performance of Constructed Facilities, 28: 8595.

YOUNG, R. G., C. D. MATTHAEI \& C. R. TOWSEND. 2008. Organic matter breakdown and ecosystem metabolism: functional indicators for assessing river ecosystem health. Journal of the North American Benthological Society, 27: 605625. 